\title{
Egg quality assessment at different storage conditions, seasons and laying hen strains
}

\section{Avaliação da qualidade do ovo em diferentes condições de armazenamento, estações do ano e linhagens de poedeiras}

\author{
Vivian Feddern', Marina Celant De Prá2, Rúbia Mores³, \\ Rodrigo da Silveira Nicoloso', Arlei Coldebella ${ }^{1}$, Paulo Giovanni de Abreu ${ }^{1 *}$
}

\author{
1Empresa Brasileira de Pesquisa Agropecuária/Embrapa, Embrapa Suínos e Aves, Concórdia, SC, Brasil \\ ¿Universidade Federal de Santa Catarina/UFSC, Florianópolis, SC, Brasil \\ ${ }^{3}$ Universidade Regional Integrada do Alto Uruguai e das Missões/URI, Erechim, RS, Brasil \\ *Corresponding author: paulo.g.abreu@embrapa.br \\ Received in February 1, 2017 and approved in April 24, 2017
}

\begin{abstract}
Eggs are one of nearly perfect protein foods, offering nutrients of great biological value. However, during storage, egg albumen and yolk components may alter and deteriorate egg quality. Therefore, the aim of this work was to assess egg quality during 9-week storage. Parameters such as Haugh unit, weight loss, egg width and length, specific gravity, yolk and albumen dimensions and their pH were evaluated weekly. A total of 270 eggs $(n=5)$ collected from two different hen strains were evaluated under room ( 20 to $35^{\circ} \mathrm{C}$ in summer; 11.2 to $29.7^{\circ} \mathrm{C}$ in autumn) and refrigerated $\left(0\right.$ to $5^{\circ} \mathrm{C}$ in summer; -3.1 to $6.5^{\circ} \mathrm{C}$ in autumn) temperatures. For storage time, an unfolding analysis was accomplished by regression analysis using orthogonal polynomials. As a second approach, principal component analysis (PCA) was performed in order to assess correlations among quality parameters on storage conditions and laying hen strains. By the end of the 9-week storage period, eggs kept under refrigeration presented similar quality parameters to eggs stored at room temperature for only 3 weeks. In contrast, eggs kept at room temperature presented faster degradation from week 1 to 5 . No differences on egg quality parameters were noticed between white and brown shells eggs. PCA suggests that better egg quality (first week) was associated mainly with higher egg weight and its specific gravity, Haugh unit and albumen height. Eggs stored at room temperature should be consumed in 2 weeks or refrigerated until 8 weeks, preserving internal quality from farm to retail.
\end{abstract}

Index terms: Weight loss; shell color; Haugh unit; yolk index.

\section{RESUMO}

Os ovos são um dos alimentos que oferecem nutrientes de grande valor biológico. Entretanto, no armazenamento, alguns componentes da clara e gema podem se alterar, deteriorando a qualidade dos ovos. Assim, este trabalho objetivou avaliar semanalmente parâmetros de qualidade como unidade Haugh, perda de peso, largura/comprimento do ovo, densidade específica, dimensões da clara/gema e pH durante 9 semanas de armazenamento. Foram coletados 270 ovos de duas linhagens de poedeiras e avaliados a temperatura ambiente (20 a $35^{\circ} \mathrm{C}$ no verão; 11,2 a $29,7^{\circ} \mathrm{C}$ no outono) e refrigerada ( 0 a $5^{\circ} \mathrm{C}$ no verão; $-3,1$ a $6,5^{\circ} \mathrm{C}$ no outono). Para as condições de armazenamento foi realizada uma análise de desdobramento por regressão por polinômios ortogonais. Ainda, análise de componentes principais (PCA), objetivou avaliar correlações entre parâmetros de qualidade em diferentes condições de armazenamento e linhagens de poedeira. Após 9 semanas de armazenamento, os ovos refrigerados apresentaram qualidade similar àqueles armazenados a temperatura ambiente por 3 semanas. Porém, sem refrigeração, os ovos apresentaram uma degradação mais rápida da semana 1 a 5 . Não foram observadas diferenças nos parâmetros de qualidade dos ovos entre as diferentes colorações de casca (linhagens de poedeiras). PCA sugere que a melhor qualidade dos ovos (primeira semana) foi associada principalmente com valores elevados de peso e densidade específica do ovo, unidade Haugh e altura do albúmen. Ovos armazenados a temperatura ambiente devem ser consumidos até duas semanas ou mantidos sob refrigeração até 8 semanas, preservando a qualidade interna desde a granja até o armazenamento no varejo.

Termos para indexação: Perda de peso; cor da casca; unidade Haugh; índice de gema.

\section{INTRODUCTION}

Eggs have been a human food and are one of nature's nearly perfect protein foods, offering nutrients of great biological value as vitamins, minerals and fatty acids daily required for growth and maintenance of body tissues (Belitz; Grosch; Schieberle, 2009). However, during egg storage, some components of albumen and yolk may alter and tend to deteriorate egg quality. The main factors directly associated to egg deterioration are temperature and relative humidity conditions, besides manipulation and storage time. An intense transformation occurs $72 \mathrm{~h}$ after posture, the dense layer becomes liquid, and consequently albumen loses its quality. Therefore, 
less time between laying and preservation methods is required, besides suitable transportation to the retail market (Oliveira; Oliveira, 2013).

From posture to consumer table, egg is subjected to physicochemical changes either in yolk or albumen that may modify flavour, freshness and palatability. The longer the storage time, worse will be the egg internal quality because carbon dioxide transfer through egg shell is favoured by temperature and humidity (Oliveira; Oliveira, 2013). Cold storage preserves eggs for 6 to 9 months, with a particularly increased shelf life with subcooled storage at $-1.5^{\circ} \mathrm{C}$ (Belitz; Grosch; Schieberle, 2009). Packing eggs under modified atmosphere increase their internal quality up to 28 days (Giampietro-Ganeco et al., 2015). However, at home, the most convenient method is to maintain eggs under refrigeration. Thus, the main objective of this research was to compare egg internal quality at both storage conditions, under refrigeration ( 0 to $5{ }^{\circ} \mathrm{C}$ ) and room $\left(20\right.$ to $35^{\circ} \mathrm{C}$ ) temperatures during 9 -week experiment. As a second approach, we intended to compare the same quality variables among eggs from different laying hen strains (different egg shell color) under the same storage conditions. Thereafter, principal component analysis (PCA) was performed will all data obtained in order to verify the association among variables and understand egg storage under this point of view. As far as we know, no literature reported all these parameters together varying different seasons, storage conditions and laying hen strains (egg shell color).

\section{MATERIAL AND METHODS}

\section{Summer season and different storage temperatures}

When hens were 77 weeks of age, 90 white eggs (Embrapa White Leghorn CC strain) were collected for three consecutive days, totalizing 270 eggs. All hens received "ad libitum" feed. From 90 collected eggs, 45 were stored at room temperature $\left(20\right.$ to $\left.35^{\circ} \mathrm{C}\right)$ and 45 eggs were cooled $\left(0\right.$ to $\left.5^{\circ} \mathrm{C}\right)$. The experiment was conducted during summer at subtropical climate (December to January).

\section{Autumn season, different storage temperatures and different egg shell color (hen strains)}

The same amount (270 eggs) was collected according to the First experiment and kept under refrigeration $\left(-3.1\right.$ to $\left.6.5^{\circ} \mathrm{C}\right)$ and at room temperature $\left(11.2\right.$ to $\left.29.7^{\circ} \mathrm{C}\right)$ equipped with air conditioner during the whole experiment, but the airflow was not directly on eggs. Half white (Embrapa White Leghorn CC strain) and half brown (Embrapa Rhode Island Red GG strain) eggs were evaluated during autumn season at subtropical climate (April to June).

\section{Methods}

Quality characteristics were measured by internal and external attributes as Haugh unit (HU), albumen and yolk pH, egg weight, weight loss, albumen and yolk height, yolk weight and diameter, yolk index, specific gravity and yolk color. In the first experiment, eggs were daily stored either at room temperature or under refrigeration. All these assays were performed along 9 weeks three times a week in 5 eggs (analyzed individually as repetition) for each treatment totalizing 270 eggs. From the data analyzed in the $1^{\text {st }}$ experiment, another one was conducted, however during autumn time. In this case, besides storage conditions already mentioned herein using the same quality attributes, different laying hen strains (White $\mathrm{CC}$ and Brown GG strains) were also evaluated.

Eggs were stored at room temperature and under refrigeration (CONTINENTAL ${ }^{\circledR}$ model RC27). Temperature variation was measured by dataloggers installed in each storage location. They were set to read the temperature and humidity every $30 \mathrm{~min}$ during the experiment.

Weight loss (\%) of whole eggs during storage was adapted from Suresh et al. (2015), according to Equation 1:

Weight loss $=\frac{\text { initial egg weight }- \text { egg weight after storage }}{\text { initial egg weight }} \times 100$

After eggs were weighed, they were broken, and the yolks were separated from the albumen. The chalazae were carefully removed from the yolk, using forceps, prior to weighing the yolk. Before weighing, all yolks were also rolled on a paper towel to remove adhering albumen. The shells were carefully washed and dried for $48 \mathrm{~h}$ in a drying oven at $21^{\circ} \mathrm{C}$ and then weighed. Albumen weight was determined by subtracting yolk and shell weights from the original egg weight, according to Suk and Park (2001).

To assess the internal quality, eggs were broken and placed on a flat surface. The albumen and yolk heights and yolk diameter were measured with a digital caliper [WORKER ${ }^{\circledR}$ (in./mm)]. From egg weight and albumen height data, Haugh unit (HU) (Haugh, 1937) was calculated following Equation 2, where $\mathrm{H}$ is the albumen height $(\mathrm{mm})$ and $\mathrm{W}$ is the egg weight $(\mathrm{g})$; yolk index (YI) was calculated dividing yolk height by its diameter (Stadelman, 1986). 
$\mathrm{HU}=100 \times \log \left(\mathrm{H}+7.57-1.7 \mathrm{~W}^{0.37}\right)$

The $\mathrm{pH}$ measurement (digital phmeter TEXTO ${ }^{\circledR}$ ) was taken individually in albumen and yolk by emerging the probe inside the sample solution. Egg yolk color was measured visually by using Roche colorimetric fan (RCF) scale, also named as DSM ${ }^{\circledR}$ yolk color fan (DSM, 2016), which is an industrial color scale varying from 1 (pale yellow) to 16 (dark orange).

Specific gravity was determined in salt $(\mathrm{NaCl})$ concentrations according to Bennett (1993), varying from 1.066 to $1.102 \mathrm{~g} \mathrm{~mL}^{-1}$. Each egg was immersed in the solution until it emerged to the surface, thereby determining the specific gravity. To measure egg length and width an electronic digital caliper was used, as mentioned for albumen and yolk.

\section{Statistical analysis}

In the first experiment, egg quality data followed analysis of variance, considering the effects of temperature, storage time (week) and interaction between them. For storage time, an unfolding analysis was accomplished by regression analysis using orthogonal polynomials. Data were processed through SAS GLM procedure (2003). For the second experiment, the effects considered were egg shell color (laying hen strain), storage time (weeks), temperature (room and refrigerated) and the interactions between them. Principal component analysis (PCA) was performed using the Excel add-in Multibase package (Numerical Dynamics, Japan) in order to assess association among egg quality parameters such as egg weight, egg specific gravity, weight loss, albumen height, $\mathrm{HU}$, albumen weight, albumen $\mathrm{pH}$, yolk $\mathrm{pH}$, yolk color, yolk height, yolk diameter on storage time (shelf life) and laying hen strains.

\section{RESULTS AND DISCUSSION}

\section{Summer season and different storage temperatures}

In our results, either stored at room or cold temperature, eggs show the same cyclical temperature. At first, room temperature varied $\left(20\right.$ to $\left.35^{\circ} \mathrm{C}\right)$ due to summer season. Secondly, the refrigerated temperature ranged from 0 to $5{ }^{\circ} \mathrm{C}$, with some peaks due to door opening during storage. Humidity also showed cyclical pattern at both refrigerated (30 to $40 \%$ ) and room (30 to $70 \%$ ) temperatures, probably due to summer time and air conditioner use. During 9 week storage, only refrigerated eggs could be evaluated until the end of the experiment. The eggs stored at room temperature were withdrawn from the experiment after the $4^{\text {th }}$ week, because as soon as eggs were opened, they were visibly rotten, with strong odor and flat surface due to the liquid albumen.

Egg starts losing water through its membrane and shell pores to the environment from the time it is laid. Water loss depends on the temperature, airflow and relative humidity $(\mathrm{RH})$ during storage. The longer the storage period, the more critical these factors become, especially under room temperature. The drier the atmosphere, the greater the water loss, thus egg vitality is also lost, affecting hatchability and chick quality (Belitz; Grosch; Schieberle, 2009). In warehouses, storage slightly above the egg freezing point $\left(-1^{\circ} \mathrm{C}\right)$ minimize water loss (Potter, 1995). Baron and Jan (2011) point out $4{ }^{\circ} \mathrm{C}$ as good storage temperature to limit microorganism migration into eggs. For storage up to 7 days, $16-17^{\circ} \mathrm{C}$ and $80 \% \mathrm{RH}$ are recommended (Daghir, 2008). Storage under $10{ }^{\circ} \mathrm{C}$ and $70-80 \% \mathrm{RH}$ are ideal to avoid humidity loss and egg weight loss. In Brazil, 92\% of in natura commercialized eggs are exposed to room temperature, being refrigerated only in the consumer's house (Oliveira; Oliveira, 2013).

In our results, comparing the $1^{\text {st }}$ week to the $4^{\text {th }}$ week of storage, egg weight decreased either at room temperature $(2.78 \mathrm{~g})$ or at refrigerated temperature (2.37 g), however egg weight was not significantly $(p>0.05)$ different among the storage conditions. The means of eggs stored at room and refrigerated temperatures were respectively 61.2 and $60.7 \mathrm{~g}$.

A study conducted in three different storage periods $(0,7,14$ days), showed $1.2 \%$ weight loss after 7 days storage and up to $2.3 \%$ after 14 days. In this experiment, weight loss was affected by breed, breeder's age, storage period and all interactions (Alsobayel; Almarshade; Albadry, 2013). Suresh et al. (2015) reported weekly difference $(p<0.05)$ in eggs coated three times with chitosan during 5-week storage. They described 5.7\% $\left(22{ }^{\circ} \mathrm{C}\right)$ and $10.6 \%\left(32{ }^{\circ} \mathrm{C}\right)$ weight loss in coated samples while non-coated samples showed $9.3 \%\left(22{ }^{\circ} \mathrm{C}\right)$ weight loss and at $32{ }^{\circ} \mathrm{C}$ it was not determined, possibly due to egg deterioration.

In our experiment, after four weeks, eggs submitted to room temperature were withdrawn due to their spoilage. Albumen height and $\mathrm{HU}$ values tend to decrease (Figure 1) during storage, which concurs with the finding of others (Caudill et al., 2010; Jones; Musgrove, 2005). 


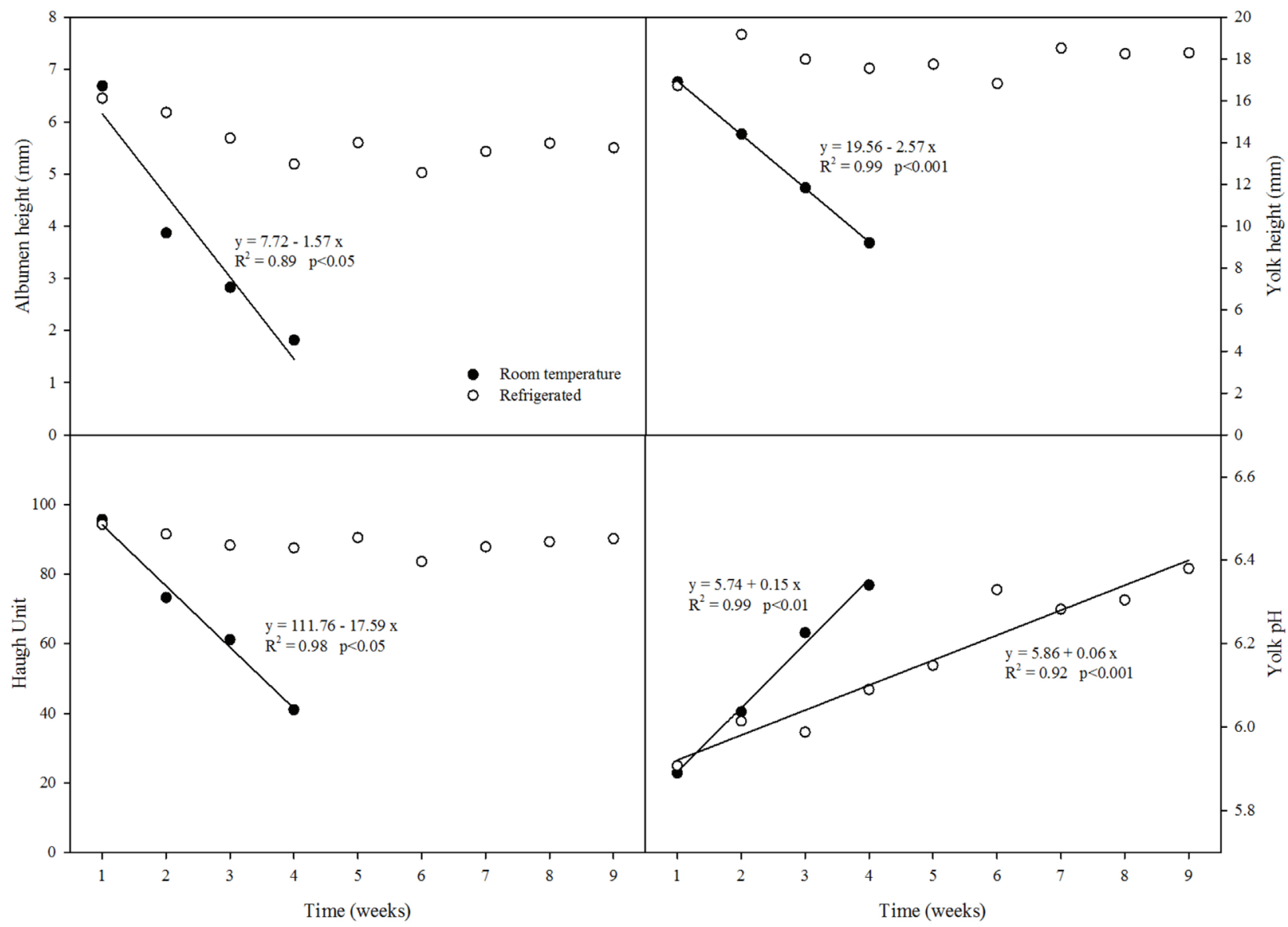

Figure 1: Albumen height, yolk height, $\mathrm{HU}$ and yolk $\mathrm{pH}$ of eggs stored at room and refrigerated temperature along 9 weeks in summer season.

Albumen height values (5.5 to $5.8 \mathrm{~mm}$ ) for different housing systems similar to our refrigerated values was also reported (Jones; Karcher; Abdo, 2014). Another research showed that albumen height decreased from 7.05 to $4.85 \mathrm{~mm}$ comparing the $1^{\text {st }}$ and $10^{\text {th }}$ week of extended cold storage (Jones; Musgrove, 2005). In our work, HU decreased significantly when eggs remained at room temperature (average temperature), especially after the $2^{\text {nd }}$ week of storage. Under refrigeration, there were no differences $(p>0.05)$ among $\mathrm{HU}$ values.

The Quality Control Program of the United States Department of Agriculture (USDA) determines quality conditions of eggs that will be consumed. According to this classification, eggs may be classified as follows: eggs of excellent quality (AA) are those that exhibit $\mathrm{HU}$ values of 72 or higher; eggs of high quality (A) are those with $\mathrm{HU}$ values between 60 and 72; and eggs of low quality (B) are those with HU values lower than 60 (USDA, 2000).
In our work, eggs with HU (83 to 94) values may be classified as AA grade up to 9 weeks at refrigerated temperatures. On the contrary, eggs stored at room temperature showed fast decline up to $4^{\text {th }}$ week $(H U=41)$, which would classify these eggs as B quality by USDA. It was recently reported (Pereira; Santos; Coelho, $2014)$ that at room temperature $\left(28^{\circ} \mathrm{C}\right)$, HU differed significantly comparing storage at day $0(\mathrm{HU}=66)$ and day $21(\mathrm{HU}=47)$. However, at refrigerated temperature $\left(5{ }^{\circ} \mathrm{C}\right)$ none of the studied days differed $(0,7,14$ and 21$)$ for this parameter. According to Giampietro-Ganeco et al. (2012), eggs stored at refrigerated temperatures had best quality up to 28 days of storage with HU values within the established standard.

Washed and unwashed eggs had lower $\mathrm{HU}$ values when stored at 5 and $25^{\circ} \mathrm{C}$ for 30 days even contaminated by $P$. aeruginosa without refrigeration. However, eggs had no contamination effect under refrigeration, proving its 
efficiency in maintaining the albumen quality, even when eggs were contaminated (Mendes et al., 2012).

As egg gets older, the dense albumen becomes liquid due to numerous chemical reactions occurring therein, possibly involving carbonic acid $\left(\mathrm{H}_{2} \mathrm{CO}_{3}\right)$ formation and increased albumen $\mathrm{pH} . \mathrm{H}_{2} \mathrm{CO}_{3}$, one of the components of albumen buffer system, dissociates to form water and carbon dioxide $\left(\mathrm{CO}_{2}\right)$. Under natural conditions, $\mathrm{CO}_{2}$ contained therein diffuses through the shell pores and evaporates, decreasing albumen acidity, increasing $\mathrm{pH}$ and chemical cleavage of the protein complex. The thickness loss of dense albumen would be associated with the natural dissociation of this complex (Oliveira; Oliveira, 2013).

Our results (Figure 1) show that albumen height, yolk height, $\mathrm{HU}$ and yolk $\mathrm{pH}$ can be expressed as a function of storage time. As these measurements are particularly related to egg freshness, it can be assumed that is important to consider that eggs were fresh and of good quality under refrigerated storage. According to the literature, decrease in those parameters are related to short shelf life, since it is claimed to be responsible for $78 \%$ and $77 \%$ decrease in $\mathrm{HU}$ and albumen height, respectively (Silversides; Villeneuve, 1994).

Mendes et al. (2012) recommend that eggs must be stored at $5{ }^{\circ} \mathrm{C}$ because refrigeration delays inner quality loss of eggs stored for up to 30 days, especially the sanitized eggs by mechanical washing (hot water with chlorhexidine $20 \%$ and $8 \%$ active content).

Our results (Table 1) showed that most refrigerated eggs are considered of good inner quality remaining stable regarding yolk index (YI), however eggs stored at room temperature showed significant differences from the $2^{\text {nd }}$ week on. Therefore, eggs stored at room temperature did not meet 0.45 as standard reference (Mertens et al., 2011) of a good YI. Also, according to Oliveira and Oliveira (2013), YI must be 0.39-0.45. Once YI is related to height and diameter, as egg gets older, these characteristics are affected, demonstrating quality loss. Giampietro-Ganeco et al. (2015) observed that YI decreased with increasing storage time. These authors found that control eggs presented $\mathrm{YI}=0.44$ and along 7, 14, 21 and 28 days of storage, the values decreased to $0.38,0.36,0.32$ and 0.32 , respectively.

In our study, at room temperature, albumen $\mathrm{pH}$ values altered from one week to another and tended to increase to 9.52 up to $4^{\text {th }}$ week storage, differing significantly $(p<0.05)$ when comparing both storage conditions from the $2^{\text {nd }}$ to the $4^{\text {th }}$ week. Whereas under refrigeration, the albumen $\mathrm{pH}$ increased among the $1^{\text {st }}$ and $2^{\text {nd }}$ week, afterwards $\mathrm{pH}$ remained stable at 8.64 until the end of the $9^{\text {th }}$ week experiment. These findings may be attributed to the inner chemical reactions which take place inside the eggs during storage, where albumen becomes liquid and $\mathrm{pH}$ increases (Oliveira; Oliveira, 2013). Oliveira et al. (2009) also verified higher value for albumens $\mathrm{pH}(9.20)$ at 50 days of storage. Albumen $\mathrm{pH}$ of freshly laid egg (7.6-7.9) may rise to 9.7 during storage due to solubilized $\mathrm{CO}_{2}$ diffusion through the shell, while yolk pH (6.0) increases slightly (6.4 to 6.9) even after long storage (Belitz; Grosch; Schieberle, 2009; Oliveira; Oliveira, 2013).

Table 1: Yolk index (YI) of eggs during different storage conditions.

\begin{tabular}{ccl}
\hline \multirow{2}{*}{ Week } & \multicolumn{2}{c}{ Treatment } \\
\cline { 2 - 3 } & Room & Refrigerated \\
\hline 1 & $0.39 \pm 0.01 \mathrm{aA}$ & $0.40 \pm 0.01 \mathrm{aA}$ \\
2 & $0.32 \pm 0.01 \mathrm{aB}$ & $0.46 \pm 0.01 \mathrm{bB}$ \\
3 & $0.24 \pm 0.02 \mathrm{aC}$ & $0.43 \pm 0.01 \mathrm{bB}$ \\
4 & $0.17 \pm 0.01 \mathrm{aD}$ & $0.42 \pm 0.01 \mathrm{bB}$ \\
5 & & $0.42 \pm 0.01 \mathrm{~B}$ \\
6 & & $0.41 \pm 0.01 \mathrm{~B}$ \\
7 & & $0.44 \pm 0.01 \mathrm{~B}$ \\
8 & & $0.42 \pm 0.01 \mathrm{~B}$ \\
9 & & $0.43 \pm 0.01 \mathrm{~B}$ \\
\hline
\end{tabular}

Means $\pm S E(n=5)$ followed by the same lowercase letters in the lines comparing storage temperatures, or same uppercase letters in the columns comparing weeks are not different according to the $\mathrm{F}$ test $(p<0.05)$.

Our study also showed that yolk $\mathrm{pH}$ increase was more intense at room temperature, whereas under refrigeration $\mathrm{pH}$ values slightly varied and only achieved in the $6^{\text {th }}$ week the same value obtained in the $4^{\text {th }}$ week at room temperature. Between the $2^{\text {nd }}$ and $5^{\text {th }}$ week no significant differences were observed. Regardless temperature at which eggs were stored, yolk $\mathrm{pH}$ increased (Figure 1) considerably along the first four weeks in eggs stored at room temperature.

It was reported that eggs stored at room temperature $\left(27-37^{\circ} \mathrm{C}\right)$ for $0,5,7$ and 10 days showed a marked albumen $\mathrm{pH}$ increase from day zero (6.86) to day five (9.32) and at day 10 the measure was not done due to spoilage (Marandi et al., 2013). These authors did not mention how spoilage was verified. However, at refrigerated temperatures, $\mathrm{pH}$ increased up to 10 days $(\mathrm{pH}=9.70)$ but no spoilage was 
mentioned. The same authors also evaluated salted eggs in the same conditions although they also observed egg spoilage at room temperature on day 10 , however $\mathrm{pH}$ was less in the end of the experiment (8.87) comparing to non-salted eggs.

Egg quality was assayed for 10 days under 5, 21 and $29{ }^{\circ} \mathrm{C}$. Albumen and yolk $\mathrm{pH}$ increased in all assays despite of the temperature. At $5{ }^{\circ} \mathrm{C}$ on days 2,5 and 10 , albumen $\mathrm{pH}$ significantly increases up to 7.99 , 8.44 and 8.26 respectively. At $21^{\circ} \mathrm{C}$ albumen $\mathrm{pH}$ was $8.52,9.17$ and 8.94 , while at $29^{\circ} \mathrm{C}$ the values were 8.70 , 9.20 and 9.11. Regarding yolk $\mathrm{pH}$, a slight difference (5.75 to 6.20) was seen in all assays (Samli; Agma; Senkoylu, 2005).

The influence of $\mathrm{pH}$ on egg quality is closely related to its freshness. It has been confirmed (Garcia et al., 2010) that albumen and yolk $\mathrm{pH}$ increased as a function of storage time and storage temperature. The authors argued that alkaline $\mathrm{pH}$ negatively influences the vitelline membrane. Also, albumen alkaline ions can be exchanged with yolk $\mathrm{H}^{+}$ions, leading to protein denaturation, increasing yolk viscosity.

Chemically, time associated to room temperature is sufficient to allow oxygen entrance into porous membrane (shell). As the oxygen tends to penetrate and contact the dispersions, the natural buffering system tends to destabilize, causing a shift of the chemical reaction to basics (Equation 3) as cited by (Souza-Soares; Siewerdt, 2005):

$2 \mathrm{HCO}_{3}^{-} \leftrightarrow \mathrm{CO}_{3}^{-2}+\mathrm{CO}_{2}+\mathrm{H}_{2} \mathrm{O}$

The oxygen entrance in egg air chamber causes volume increase. The hydrogen bonded to aminoacids can be detached through oxidation reactions. At the time the oxidation reaction occurs, hydrogen atoms are able to bond to free oxygen, thus forming water. According to the chemical reaction (Equation 3), water formed along with carbon dioxide catalyzes $\mathrm{HCO}_{3}$ ion formation in the same proportion in which oxygen enters the medium, that is, at room temperature which favors this reaction (Oliveira; Oliveira, 2013).

Yolk color is the most inner characteristic observed by the consumer. Although preferences vary, consumers in most countries prefer an egg yolk color with a DSM YolkFan ${ }^{\mathrm{TM}}$ value of 12 or more (DSM, 2016), tended to dark orange. Yolk colorimetric analysis had as purpose to survey sensory characteristics of eggs, being closely related to the feed. Feeding is a predominant factor for yolk color to be lighter or darker. In our study, no variability among treatments was observed. The mean \pm SE was $7.33 \pm 0.51$. Most eggs were classified in the middle of the color scale at score 7 (68\%), 30\% of the eggs scored 8 and only $2 \%$ scored 9 . Santos et al. (2009) verified that yolk color decreased from 9.3 to 8.5 at room temperature and from 9.8 to 9.3 under refrigeration whereas in the present work this decrease was from 8.0 to 7.5 at room temperature and from 7.4 to 7.1 at refrigerated temperature.

Regarding specific gravity, no variability was verified in our treatments. Mean $\pm \mathrm{SE}$ was $1.068 \pm$ $0.005 \mathrm{~g} \mathrm{~mL}^{-1}$ pointing out that almost $80 \%$ of the eggs showed specific gravity between 1.066 and $1.07 \mathrm{~g} \mathrm{~mL}^{-1}$, demonstrating the uniformity and quality of eggs. Either length or width values were not different $(p>0.05)$ among the treatments being the mean values among the nine weeks of experiment $60.0 \mathrm{~mm}$ length $\mathrm{x} 44.3 \mathrm{~mm}$ width at room temperature and $59.6 \mathrm{~mm} \times 43.8 \mathrm{~mm}$ at refrigerated temperatures.

\section{Autumn season, different storage temperatures and different egg shell color (hen strains)}

Seventeen evaluated variables were: albumen height $(\mathrm{mm})$, yolk height $(\mathrm{mm})$, egg area $\left(\mathrm{mm}^{2}\right)$, egg length $(\mathrm{mm})$, egg width $(\mathrm{mm})$, egg weight loss $(\%)$, albumen weight $(\mathrm{g})$, shell weight $(\mathrm{g})$, yolk weight $(\mathrm{g})$, egg weight $(\mathrm{g})$, yolk color, specific gravity $\left(\mathrm{g} \mathrm{mL}^{-1}\right)$, yolk diameter (mm), yolk pH, albumen $\mathrm{pH}$, Haugh unit and egg volume $\left(\mathrm{mm}^{3}\right)$.

When evaluating different hen strains (brown shell and white shell color) separately, only yolk color, yolk height, yolk diameter, yolk pH, shell weight, egg weight, egg width and egg density were statistically significant $(p<0.05)$.

When evaluating treatments (refrigerated or not) separately, the following ten parameters differed $(p<$ 0.05): egg density, egg weight, weight loss, yolk height and diameter, yolk $\mathrm{pH}$, albumen $\mathrm{pH}$, albumen height, albumen weight, Haugh Unit.

When comparing the interaction of both egg shell color (white or brown) and treatment (room temperature or refrigerated storage), differences $(\mathrm{p}<0.05)$ were observed only in egg specific gravity and yolk diameter. However, the interaction between egg shell color (hen strains) and storage time along 9 weeks, showed difference $(p<0.05)$ in egg weight, egg volume and albumen weight.

The storage time was the most important factor of egg quality being different $(p<0.05)$ for 12 out of 
17 evaluated variables, influencing all inner quality characteristics of eggs, besides weight loss, egg weight and specific gravity. A strong correlation was also observed when temperature was compared to storage time, influencing $(p<0.05)$ all parameters mentioned before, with the exception of egg weight. On the contrary, when egg shell color was compared to storage time or even with temperature and time, most variables did not differ $(p>0.05)$.

Table 2 summarizes only the significant variables regarding different storage conditions and their values found during each week along 9 -week experiment. The other variables (full data not presented) did not differ and the main values among the whole experiment for eggs submitted to room temperature and refrigerated temperature are respectively: 5,388.29 and 5,419.67 $\mathrm{mm}^{2}$ for egg area, 53.33 and $53.44 \mathrm{~mm}$ for egg length, 40.54 and $40.72 \mathrm{~mm}$ for egg width, 4.59 and $4.63 \mathrm{~g}$ for egg shell weight, 12.57 and $12.48 \mathrm{~g}$ for yolk weight and finally $46,749.98$ and $47,229.09 \mathrm{~mm}^{3}$ for egg volume. As can be seen, most quality variables differed among storage conditions, what was also verified in the first experiment. It seems that albumen $\mathrm{pH}$ is more sensible to storage conditions, once it differed significantly each week comparing eggs stored either at room temperature or under refrigeration, varying from 7.9 to 9.2 , whereas yolk $\mathrm{pH}$ varied narrowly from 5.8 to 6.6, close to values found by Caner and Yüceer (2015). However, in refrigerated eggs, yolk $\mathrm{pH}$ differed at $5^{\text {th }}, 8^{\text {th }}$ and $9^{\text {th }}$ week, being stable in the first four weeks. Egg specific gravity, yolk height and yolk diameter differed from the $2^{\text {nd }}$ week on, being the egg specific gravity and yolk height lower in eggs at room temperature, and yolk diameter was higher in these eggs. Weight loss and HU decreased significantly and are further discussed.

Regarding the same variables evaluated under different laying hen strains (white eggs and brown eggs), most of them did not differ along the weeks (Table 3). Although, it was observed that area, weight, volume and albumen weight of eggs tended to differ after 7-week storage, it only occurred in these external mentioned variables.

Hermiz et al. (2012) evaluated different laying hen strains and noticed significant $(p<0.01)$ differences among laying hen strains regarding egg weight, although $\mathrm{HU}$ were significantly different due to storage period only.
Figure 2 shows respectively egg weight loss and $\mathrm{HU}$ along 9-week experiment. There is a linear decrease in egg weight despite the storage condition or the egg shell color (different laying hen strains). However, this decrease is more pronounced in eggs submitted to room temperature, achieving $\sim 9 \%$ weigh loss for either white or brown eggs. For refrigerated eggs, this loss was only $<6 \%$ in the end of $9^{\text {th }}$ week. It was reported $6.7 \%$ weight loss and $\mathrm{HU}=58.93$ at $5^{\text {th }}$ week experiment at room temperature $\left(24{ }^{\circ} \mathrm{C}\right)$ (Caner; Yüceer, 2015). Decreased HU values (Figure 2) were verified for all eggs, meanwhile under refrigeration eggs still show HU $>62$ which according to Stadelman (USDA, 2000) are eggs of high quality (A) because our values lay between 60 and 72.

Principal component analysis (PCA) was performed in order to assess the variation of egg quality parameters along time (up to 9 weeks) according to storage temperature and different laying hen strains. The first two ordination axes represented $81.9 \%$ of the variability of egg quality parameters according to storage temperature (Figure 3). The principal component 1 (PC1) had higher correlation with egg weight $(r=0.34)$, albumen weight $(r=0.35)$, Haugh unit $(r=0.35)$, yolk $\mathrm{pH}(\mathrm{r}=0.32)$, albumen $\mathrm{pH}(\mathrm{r}=0.33)$, albumen height $(\mathrm{r}$ $=0.35)$, egg specific gravity $(\mathrm{r}=0.35)$, and yolk diameter $(\mathrm{r}=0.35)$. On the other hand, the principal component 2 (PC2) represented better the variability of weight loss ( $\mathrm{r}$ $=0.47)$, yolk color $(r=0.63)$, and yolk height $(r=0.40)$. Better egg quality (measured at week 1 ) was associated with higher egg- (EW) and albumen weight (AW), Haugh unit (HU), albumen height (AH) and egg specific gravity (ESG). Eggs stored under refrigeration had lower variability on quality parameters than eggs stored under room temperature. By the end of the 9-week storage period, eggs kept under refrigeration presented similar quality parameters to eggs stored at room temperature for only 3 weeks. In contrast, eggs kept at room temperature presented faster degradation from week 1 to 5 . From week 5 to 9 , eggs stored at room temperature had low variation on egg quality parameters, indicating complete loss of quality for retailing. Lower egg quality, as measured at weeks 5-9 for eggs stored at room temperature was, for instance, closely associated with higher yolk $\mathrm{pH}(\mathrm{YpH})$ and yolk diameter (YD). PCA suggests that eggs stored at room temperature should be consumed in 2 weeks or kept under refrigeration for up to 8 weeks. 


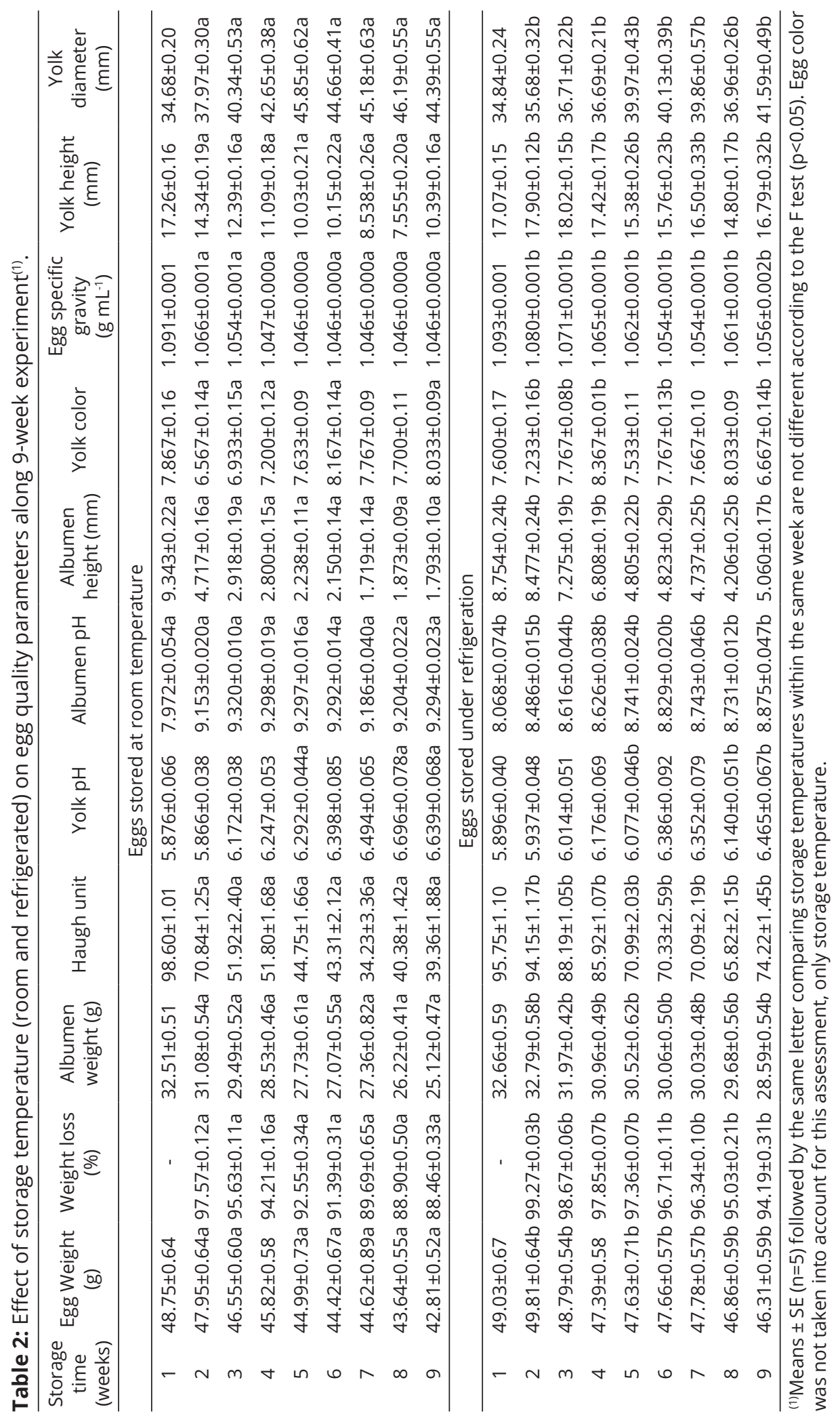




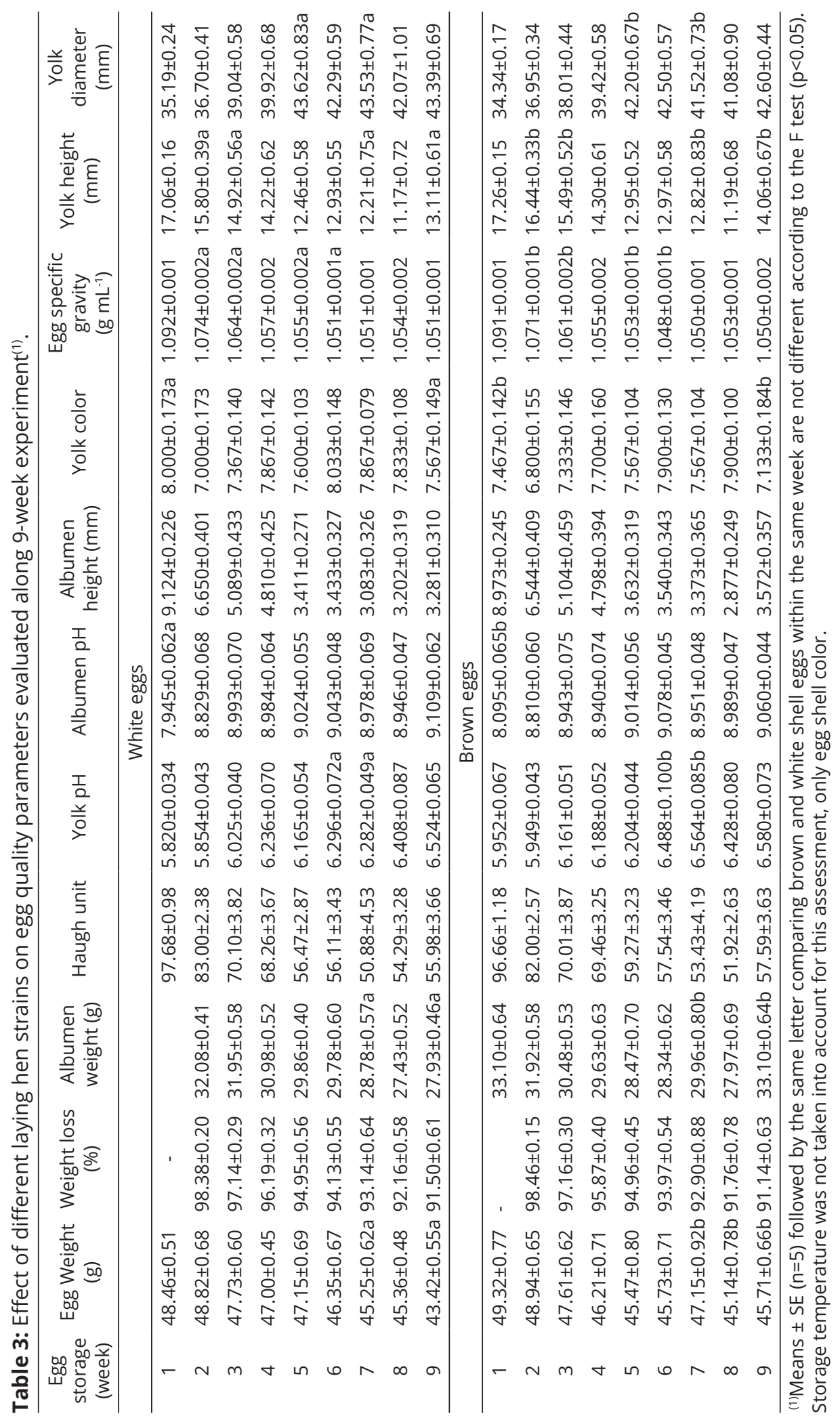




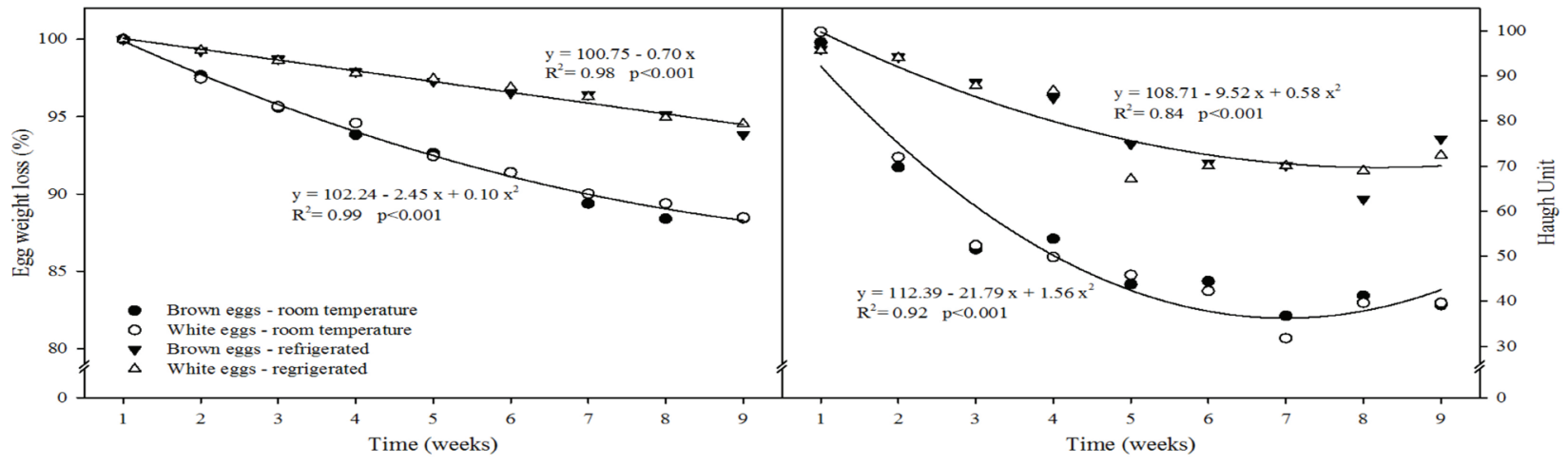

Figure 2: Egg weight loss (\%) and HU according to different storage conditions (eggs submitted to room temperature and to refrigeration) along 9 weeks in autumn season.

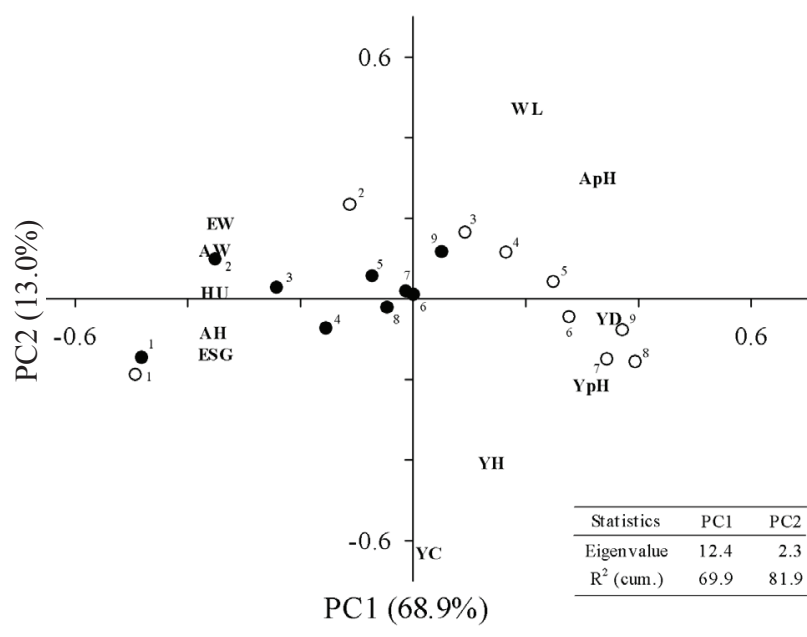

Figure 3: PCA for egg quality parameters according to storage temperature: room (white circles) and refrigerated (black circles). The numbers (1-9) next to the circles refer to the storage time (weeks). (EW = egg weight; $\mathrm{AW}=$ albumen weight; $\mathrm{HU}=$ Haugh unit; $\mathrm{AH}=$ albumen height; $\mathrm{YH}=$ yolk height; $\mathrm{ApH}=$ albumen $\mathrm{pH} ; \mathrm{YpH}=$ yolk $\mathrm{pH} ; \mathrm{ESG}=$ egg specific gravity; $\mathrm{YD}=$ yolk diameter; $\mathrm{YC}=$ yolk color; $\mathrm{WL}=$ weight loss).

PCA for egg quality parameters according to white and brown shell eggs from different laying hen strains indicate that the first two ordination axes represented $88.5 \%$ of the total variability along the 9 storage weeks (Figure 4). The principal component 1 (PC1) had higher correlation with egg weight $(\mathrm{r}=0.30)$, Haugh unit $(\mathrm{r}=0.35)$, yolk $\mathrm{pH}$ $(\mathrm{r}=0.30)$, albumen $\mathrm{pH}(\mathrm{r}=0.32)$, albumen height $(\mathrm{r}=0.36)$, egg specific gravity $(\mathrm{r}=0.35)$, yolk height $(\mathrm{r}=0.33)$, and yolk diameter $(\mathrm{r}=0.34)$. On the other hand, the principal component 2 (PC2) represented better the variability of weight loss $(r=0.36)$, albumen weight $(r=0.54)$, and yolk color $(\mathrm{r}=0.61)$. Better egg quality (measured at week 1$)$ was associated with higher egg weight $(\mathrm{EW})$, yolk height $(\mathrm{YH})$, Haugh unit (HU), albumen height $(\mathrm{AH})$ and egg specific gravity (ESG). No differences on egg quality parameters were noticed between white and brown shells eggs. However, regarding storage conditions, both white and brown shell eggs had faster degradation of egg quality from week 1 to 5 , as already observed for eggs stored at room temperature. From week 5 to 9, variation on egg quality parameters was negligible, indicating complete quality loss for retailing. Higher yolk $\mathrm{pH}(\mathrm{YpH})$ and diameter (YD) were again indicative of lower egg quality (as measured at weeks 5-9). PCA revealed that both white and brown shell eggs present the same quality and shelf life when compared to storage conditions.

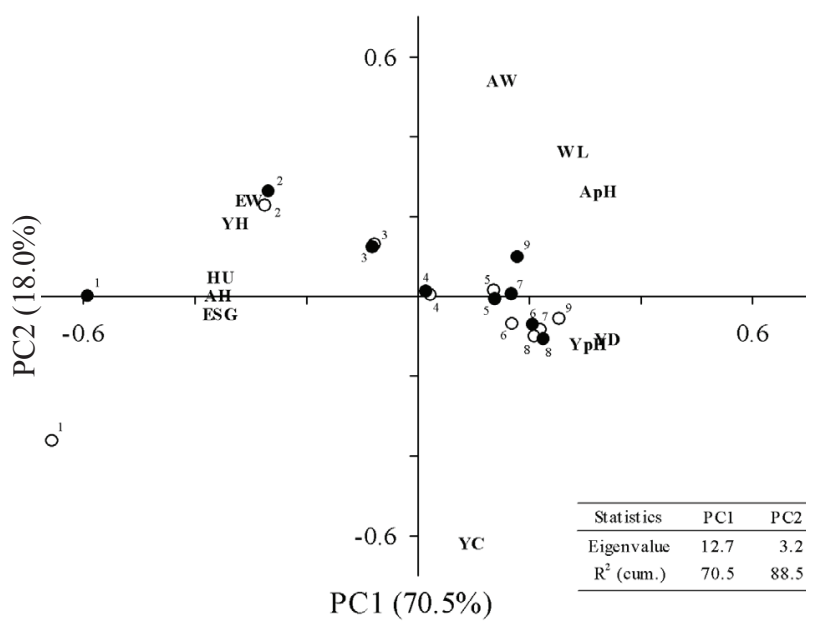

Figure 4: PCA for egg quality parameters according to different laying hen strains: white shell (white circles) and brown shell (black circles). The numbers (1-9) next to the circles refer to the storage time (weeks). 


\section{CONCLUSIONS}

Eggs stored under refrigeration had lower variability on quality parameters than eggs stored under room temperature. YI and $\mathrm{pH}$ values of refrigerated eggs satisfied international quality standards. By the end of 9-week storage period, eggs kept under refrigeration presented similar quality parameters to eggs stored at room temperature for only 3 weeks. In contrast, eggs kept at room temperature presented faster degradation from week 1 to 5; after that, eggs had low variation on quality parameters, indicating complete quality loss for retailing. PCA suggests that eggs stored at room temperature should be consumed in 2 weeks or kept under refrigeration for up to 8 weeks. No differences on egg quality parameters were noticed between white and brown shells eggs. Better egg quality (measured at week 1) was associated with higher egg weight, yolk and albumen height, HU and egg specific gravity.

\section{REFERENCES}

ALSOBAYEL, A. A.; ALMARSHADE, M. A.; ALBADRY, M. A. Effect of breed, age and storage period on egg weight, egg weight loss and chick weight of commercial broiler breeders raised in Saudi Arabia. Journal of the Saudi Society of Agricultural Sciences, 12(1):53-57, 2013.

BARON, F.; JAN, S. Egg and egg product microbiology. In: NYS, I.; BAIN, M.; VAN IMMERSEEL, F. (Eds.). Improving the safety and quality of eggs and egg products. Volume 1: Egg chemistry, prodution and consumption. 1.ed. Cambridge: Woodhead Publishing Limited, 2011. p.330-350.

BELITZ, H. D.; GROSCH, W.; SCHIEBERLE, P. Food Chemistry. 4. ed. Berlin, Heidelberg: Springer Berlin Heidelberg, 2009. 1070p.

BENNETT, C. D. Measuring table egg shell quality with one specific gravity salt solution. The Journal of Applied Poultry Research, 2(2):130-134, 1993.

CANER, C.; YÜCEER, M. Efficacy of various protein-based coating on enhancing the shelf life of fresh eggs during storage. Poultry Science, 94(7):1665-1677, 2015.

CAUDILL, A. B. et al. The effects of commercial cool water washing of shell eggs on Haugh unit, vitelline membrane strength, aerobic microorganisms, and fungi. Poultry Science, 89(1):160-168, 2010.

DAGHIR, N. J. Broiler feeding and management in hot climates. In: DAGHIR, N. J. (Ed.). Poultry Production in Hot Climates. 2. ed. Trowbridge: CAB International. Cromwell Press, 2008. p.227-260.
DSM. DSM egg yolk pigmentation guidelines 2016. Heerlen, The Netherlands: (c) DSM Nutritional Products Ltd 2016. Available in: <https://www.dsm.com/content/dam/dsm/ anh/en_US/documents/DSM_EggYolk_Pigmentation_ Guidelines_2016.pdf>. Access in: 28 April 2017.

GARCIA, E. R. de M. et al. Quality of eggs of lay hens stored at different temperature and storage conditions. Revista Brasileira de Saúde e Produção Animal, 11(2):505-518, 2010.

GIAMPIETRO-GANECO, A. et al. Comparative study of quality characteristics of egg stored in domestic refrigerators. Ars Veterinaria, 28(2):100-104, 2012.

GIAMPIETRO-GANECO, A. et al. Quality assessment of eggs packed under modified atmosphere. Ciência e Agrotecnologia, 39(1):82-88, 2015.

HAUGH, R. R. The Haugh unit for measuring egg quality. U.S. Egg Poultry Magazine, 43:522-555, 1937.

HERMIZ, H. N. et al. Effect of strain and storage period on egg quality characteristics of local Iraqi laying hens. Research Opinions in Animal \& Veterinary Sciences, 2(1):98-101, 2012.

JONES, D. R.; KARCHER, D. M.; ABDO, Z. Effect of a commercial housing system on egg quality during extended storage. Poultry Science, 93(5):1282-1288, 2014.

JONES, D. R.; MUSGROVE, M. T. Effects of extended storage on egg quality factors. Poultry science, 84(11):1774-1777, 2005.

MARANDI, S. et al. Quality changes in salted chicken eggs. International Journal of Food Nutrition and Safety, 3(1):7-14, 2013.

MENDES, F. R. et al. Physical and chemical quality of sanitized commercial eggs experimentally contaminated with Pseudomonas aeruginosa and refrigerated during storage. Revista Brasileira de Zootecnia, 41(10):2211-2218, 2012.

MERTENS, K. et al. Advances in egg defect detection, quality assessment and automated sorting and grading. In: NYS, I.; BAIN, M.; VAN IMMERSEEL, F. (Eds.). Improving the safety and quality of eggs and egg products. Volume 1: Egg chemistry, prodution and consumption. 1. ed. Cambridge: Woodhead Publishing Limited, 2011. p.209-241.

OLIVEIRA, B. L. de; OLIVEIRA, D. D. de. Qualidade e Tecnologia de Ovos. 1. ed. Lavras, MG: UFLA, 2013. 223p.

OLIVEIRA, G. E. et al. Bioactive amines and quality of egg from Dekalb hens under different storage conditions. Poultry science, 88(11):2428-2434, 2009. 
PEREIRA, A. S.; SANTOS, T. T. dos; COELHO, A. F. S. Quality of eggs sold in different commercial establishments and the study of the conditions of storage. Food Science and Technology, 34(1):82-87, 2014.

POTTER, N. N. Meat, poultry, and eggs. In: POTTER, N. N. (Ed.). Food Science. 5. ed. Ithaca, New York: Springer Science \& Business Media, 1995. p.316-343.

SAMLI, H. E.; AGMA, A.; SENKOYLU, N. Effects of storage time and temperature on egg quality in old laying hens. The Journal of Applied Poultry Research, 14(3):548-553, 2005.

SANTOS, M. do S. V. dos et al. Effect of temperature and storage of eggs. Food Science and Technology, 29(3):513-517, 2009.

SILVERSIDES, F. G.; VILLENEUVE, P. Is the Haugh Unit correction for egg weight valid for eggs stored at room temperature? Poultry Science, 73(1):50-55, 1994.
SOUZA-SOARES, L. A. de; SIEWERDT, F. Aves e ovos. 1. ed. Pelotas: Ed. da Universidade UFPEL, 2005. v. 13. 138p.

STADELMAN, W. J. Quality identification of shell eggs. In: STADELMAN, W.; COTTERILL, O. (Eds.). Egg science and technology. Westport, Conn.: AVI Publishing, 1986. p.37-61.

SUK, Y. O.; PARK, C. Effect of breed and age of hens on the yolk to albumen ratio in two different genetic stocks. Journal of Animal Science, 80(7):855-858, 2001.

SURESH, P. V. et al. Application of chitosan for improvement of quality and shelf life of table eggs under tropical room conditions. Journal of Food Science and Technology, 52(10):6345-6354, 2015.

USDA. Unites States Department of Agriculture. Egg-Grading Manual. 56p. 2000. Available in: <https://www.ams.usda. gov/publications/content/egg-grading-manual>. Access in: 28 April 2017. 